\title{
A HISTÓRIA DE EXCLUSÃO SOCIAL E CONDENAÇÀO MORAL DA PROSTITUIÇÃO
}

\section{THE HISTORY OF SOCIAL EXCLUSION AND MORAL CONDEMNATION OF PROSTITUTION}

\author{
${ }^{1}$ Maria Cecília Máximo Teodoro \\ ${ }^{2}$ Thais Campos Silva
}

\section{RESUMO}

A partir de um relato histórico minucioso, este artigo se propõe a demonstrar a história de exclusão social e de condenação moral da prostituição. Optou-se por abordar a prostituição da mulher, tendo em vista ser este gênero o que compõe a grande maioria de trabalhadores desta atividade. Abordar-se-á a atividade da prostituição desde a sua concepção enquanto divindade à sua passagem esteriotipada pela bíblia, até chegarmos no século XXI e verificar as condições em que seu trabalho é prestado e julgado. Embora esta atividade seja considerada uma profissão, na medida em que faz parte do Código Brasileiro de Ocupações e possui código de recolhimento previdenciário, o relato histórico aqui apresentado traz à tona uma realidade histórica de exclusões no passado e no presente, alertando, assim, para a uma necessária mudança cultural, social, moral e, principalmente, jurídica, no sentido de se conferir dignidade a estas mulheres, tendo em vista os seres humanos que são.

Palavras-chave: Prostituição, Relato histórico, Exclusão social e condenação moral

\begin{abstract}
From a detailed historical account, this article aims to demonstrate the history of social exclusion and moral condemnation of prostitution. It was decided to address the prostitution of women, given that this genre that makes up the vast majority of workers in this activity. It will address the prostitution activity since its inception while divinity in his wake stereotyped by the Bible, until we reached the twenty-first century and verify the conditions under which their work is performed and judged. Although this activity is considered a profession, as part of the Brazilian Code of Occupations and has social security contribution of code, the historical record presented here brings up a historical reality exclusions in the past and present, alerting, so for a necessary cultural change, social, moral and mainly legal in the sense of giving dignity to these women.
\end{abstract}

Keywords: Prostitution, Historical account, Social exclusion and moral condemnation

\footnotetext{
${ }^{1}$ Doutora em Direito do Trabalho e da Seguridade Social pela Universidade de São Paulo, USP, São Paulo - SP (Brasil). Professora da Pontifícia Universidade Católica de Minas Gerais - PUC, Belo Horizonte - MG (Brasil). E-mail: cecimax @ pucminas.br

${ }^{2}$ Mestre em Direito pela Pontifícia Universidade Católica de Minas Gerais- PUC, Belo Horizonte - MG (Brasil). E-mail: thais@ hipolitocsilva.adv.br
} 


\section{INTRODUÇÃO}

A atividade das profissionais do sexo existe há milhares de anos, tendo ela ocupado diferentes posições no cenário social.

Não é tarefa fácil, entretanto, encontrar registros da profissão, principalmente elaborados diretamente pelas profissionais, tendo em vista que a grande maioria dos escritos ao longo da história foi feita por homens. Dentre eles, aqueles que eram responsáveis pelas produções literárias ou científicas em geral estavam no topo da pirâmide social, eram nobres e por isso tinham acesso aos estudos.

Considerando essa realidade, há que se identificar que eles registravam o momento a partir de suas concepções, seja na condição de clientes ou de expectadores. A visão era, portanto, masculina.

Muitos autores, e até mesmo o senso comum, dizem que a prostituição é a profissão mais antiga do mundo. Considerar verdadeira essa assertiva torna ainda mais imprescindível trazer à tona o debate saudável, respeitoso e científico sobre o tema. A análise histórica tem papel importante na formação de opinião e na produção do conhecimento. Tem o presente artigo a finalidade de fazer um apanhado da história da prostituição, buscando perceber a exclusão social a que essas pessoas foram submetidas. Não se constrói um futuro digno, esquecendo-se do passado.

Já são muitos anos de descaso do Estado, das instituições acadêmicas e até das entidades religiosas para com as pessoas que exercem a profissão.

Nesse sentido, Margareth Rago (2008, p. 14) afirma:

considerar a prostituição como 'a profissão mais antiga do mundo' é uma postura que mais prejudica do que ajuda, pois favorece a naturalização de um fenômeno que é cultural e histórico (...) ignorá-la e silenciar a seu respeito, como acontece nos meios acadêmicos e políticos, de esquerda ou de direita, também é uma maneira de fechar os olhos a problemas que assolam a nossa vida social. (grifos nossos)

Alguns conceitos são importantes para iniciar o estudo da evolução histórica da profissão; dentre eles, o próprio conceito de prostituição. Segundo o dicionário Houaiss (2004, p. 603), prostituir-se significa "ter relações sexuais em troca de dinheiro" e prostituta "a mulher que ganha dinheiro para manter relações sexuais".

Prosseguindo a leitura do conceito, depara-se com a segunda definição do verbo prostituir-se: "rebaixar (-se) moralmente; degradar (-se), corromper (-se)". Pela simples 
análise, percebe-se que o significado trazido pelo próprio dicionário carrega forte conteúdo moralista, remetendo a prostituição a algo negativo, indigno e inferiorizado.

Em outubro de 2002, o Ministério do Trabalho e Emprego, por meio da Portaria Ministerial $n^{\circ}$. 397, incluiu as profissionais do sexo na Classificação Brasileira de Ocupações - CBO. Segundo o sítio eletrônico do próprio órgão, a lista não tem o objetivo de regulamentar a atividade, mas somente identificar as "ocupações no mercado de trabalho, para fins classificatórios junto aos registros administrativos e domiciliares”. (BRASIL, 2002)

O código que se refere às profissionais do sexo é 5198-05, sendo que a Classificação prevê como sinônimos os seguintes termos: garota de programa, garoto de programa, meretriz, messalina, michê, mulher da vida, prostituta, trabalhador do sexo. Neste trabalho, os termos prostituta e profissional do sexo serão os adotados e também serão utilizados como sinônimos.

A Classificação aponta as seguintes atividades como sendo ligadas às prostitutas: "buscam programas sexuais; atendem e acompanham clientes; participam em ações educativas no campo da sexualidade”. (BRASIL, 2002)

A Classificação trazida pelo Ministério do Trabalho e Emprego amplia a atividade das profissionais do sexo, que não se restringe, portanto, apenas à prática sexual mediante pagamento, conforme conceito trazido pelo dicionário.

Esse trabalho opta por utilizar o termo "prostituta" sempre no feminino, por entender que as mulheres ainda constituem a maioria dos que atuam na profissão. O termo cafetão será utilizado sempre no masculino, prestigiando, assim, a história, conforme se verá.

O objetivo do presente trabalho é, como dito, analisar a evolução histórica da profissão e constatar o desamparo das profissionais do sexo que ainda paira na sociedade. Por essa razão, a análise tem início na Antiguidade, cerca de 10.000 anos a.C e finda no século XX.

\section{A MULHER COMO DEUSA}

A sociedade já foi matricêntrica, momento em que "a mulher é que era considerada a criadora da força da vida. Ela era adorada como a Grande Deusa e como tal estava no centro de toda a atividade social”. (ROBERTS, 1998, p. 19) 
Nesse período, mais de 10.000 anos a.C., as mulheres participavam das atividades das comunidades, compartilhavam os momentos de plantio, de colheita, criavam recipientes para armazenar as comidas e objetos, cuidavam do lar e da educação dos filhos. A mulher, em algumas sociedades, era considerada uma Deusa, pela capacidade de produzir seres humanos em seus corpos.

Ritos sexuais eram praticados de forma natural, em sinal de adoração e agradecimento às Deusas. Grande quantidade de filhos representava bênçãos divinas sobre aquele grupo.

A sociedade começou a inverter o pensamento por volta de 3.000 a.C., quando tribos de homens nômades invadiram essas comunidades, subjugando o povo e sujeitando-o ao que eles entendiam como correto e, assim, determinando a prevalência do poder masculino. (ROBERTS, 1998, p. 22). Esses grupos já possuiam o conhecimento da importância do homem na reprodução, sendo que as primeiras civilizações foram sendo formadas na região da Mesopotâmia e no Egito.

Deve-se observar que o poder matricêntrico prevaleceu durante longo período, mas a imposição masculina foi tão poderosa e veemente que a mulher passou a ter papel apenas secundário na sociedade, estando até hoje na luta pela efetiva igualdade de direitos.

Segundo Friedrich Engels, a origem da família monogâmica buscou atender a anseios econômicos, para garantir a transferência de bens e o acúmulo de capital apenas em determinado núcleo familiar. Para tanto, as mulheres deveriam relacionar-se apenas com um homem (1986, p. 32), regra essa que não necessariamente deveria ser seguida pelo sexo masculino.

Deuses com figura masculina foram introduzidos na cultura da sociedade que era matriarcal para modificar o paradigma anterior. Do mesmo modo, os cargos de administração foram tomados pelos homens, que passaram a produzir normas com o objetivo de controlar a sociedade e resguardar seus interesses.

Visando permanecer com a adoração às Deusas, muitas mulheres mantiveram os rituais sexuais que praticavam quando a sociedade ainda era matriarcal. Os líderes, percebendo que não seria possível acabar completamente, em curto espaço de tempo, com essas práticas, permitiram que fossem realizadas exclusivamente nos templos, sob o controle dos homens sacerdotes.

Uma das principais Deusas, venerada em muitas regiões, foi a Ishtar, conhecida como Deusa da Fertilidade, aquela que dava o poder da reprodução e do crescimento. Foi venerada 
como Astarte em Canaã, Star na Mesopotâmia, Astar e Star na Arábia, Estar na Abissínia, Stargatis na Síria, Astarte na Grécia e Isis no Egito. (FAUR, 2011)

É nesse contexto que surgiu a prostituição, entendida como atividade em que se tinha lucro por meio da oferta de serviços sexuais, eis que nesses locais se estipulava um preço para realização do rito sexual.

Por ser ainda um ritual que possuía certa importância naquela sociedade, principalmente na região da Mesopotâmia, a prostituição nasceu sem carregar concepção negativa, recebendo inclusive o apreço da sociedade, com reconhecido status pela tarefa desempenhada: "uma prostituta desempenha um papel crucial; e ela não é apenas reconhecida como sendo sagrada - seu trabalho também é considerado civilizador". (ROBERTS, 1998, p. 23)

Nesse momento, como dito, o modelo de sociedade já era patriarcal. As mulheres viviam para os homens, ou seja, cumprindo suas ordens e cuidando dos afazeres exclusivamente domésticos; já não cabia a elas práticas ligadas ao plantio, colheita, criação de materiais, entre outras.

As profissionais do sexo que praticavam os ritos sexuais nos templos já se diferenciavam das mulheres do lar, vez que recebiam valores em razão dos ritos sexuais praticados, passando a participar da atividade econômica da comunidade (LOPES, 2006, p.2627). Elas podiam, portanto, adquirir bens e usufruir privilégios não extensivos às demais mulheres.

Com o tempo, algumas prostitutas que viviam na região da Babilônia, e que foram denominadas harimtu, decidiram parar de trabalhar nos templos para fazê-lo nas ruas, sendo que ainda nessas condições "a conexão entre sexo e religião persistia, pois as prostitutas de rua continuavam a ser consideradas mulheres sagradas, protegidas por Ishtar", a deusa (ROBERTS, 1998, p. 26), mas continuaram estipulando preço para a prática sexual.

Por volta de 2.000 a.C., na região da Suméria, ao sul da Mesopotâmia, surgiram as primeiras leis, ora concedendo pretensos direitos, ora segregando as profissionais do sexo. Dentre elas, uma lei estabelecia que se alguma dessas mulheres engravidasse de um homem casado, cuja esposa não tivera filhos, os filhos dessas seriam reconhecidos como herdeiros e o homem deveria provê-la, mas a ela não seria dado o direito de viver com esse homem. (ROBERTS, 1998, p. 27). Utiliza-se aqui a ideia de pretensos direitos, pois se percebe claramente que não há qualquer preocupação com as prostitutas; a norma parece buscar resguardar somente o homem que não tenha outros descendentes; a preocupação é claramente 
voltada ao homem, sequer a criança, vez que caso haja outros herdeiros, o filho gerado pela prostituta não teria qualquer proteção.

A lei mencionada refletia ainda a ideologia que começava a ser difundida: as profissionais do sexo eram más e que seria impossível a um homem viver e conviver com elas. Percebe-se, assim, que a imagem da prostituta vai sendo modificada, tornando-se negativa à sociedade, em constante dicotomia com a imagem da mulher ideal, ligada ao lar e obediente ao homem. Aos poucos perde-se também a ideia de santidade da mulher e da existência de Deusas a protegê-las. No lugar disso, a sociedade torna-se cada vez mais patriarcal e a distância entre a "mulher da rua" e a "mulher da casa" torna-se maior.

Os homens desejavam, assim, "mulheres de bem" em suas casas, como esposas e filhas, mas, não satisfeitos de forma plena com essa condição estabelecida socialmente, procuravam nas ruas as profissionais do sexo para saciar outros desejos. Talvez, entre esses desejos, não estejam apenas os sexuais; poder-se-ia pensar na busca do homem por mulheres de virtudes intelectuais, para trocarem ideias sobre o mundo exterior ao lar. Algumas prostitutas possuiam estudo, sabiam filosofia, política e artes.

Para derrubar a ideia de poder sagrado foi necessário introduzir e propagar um sistema moralista que reprimia o sexo, valorizava a mulher virgem e tornava pecadoras as prostitutas. Por certo que esse processo levou muitos anos e foi se consolidando com o tempo.

As profissionais do sexo, no entanto, permaneceram por algum tempo com seus propósitos: "elas continuavam ligadas às suas tradições de adoração à Deusa e afirmavam ardorosamente seu desejo de viver independentemente do 'homem', escolhendo a prostituição como carreira”. (ROBERTS, 1998, p. 30)

Dando um pequeno salto na história, encontra-se na Grécia Antiga, por volta de 1.000 anos a.C., sociedade patriarcal, em que os homens que detinham o poder econômico conseguiam manter bons casamentos e também frequentar os bordéis sem sofrer qualquer represália social.

A ideia de "mulher de bem" consolidava-se. Ela deveria servir ao lar e à família, sendo que a educação recebida restringia-se às tarefas que deveriam cumprir. Era ela propriedade do homem, primeiro do pai e depois do marido; sequer tinha autorização para andar nas ruas desacompanhada do homem responsável.

As prostitutas não se enquadravam nessas condições de submissão. Elas eram livres, conseguiam comprar o que bem quisessem com o dinheiro que adquiriam na prática sexual e, 
por isso, representavam uma ameaça àqueles que desejavam manter a situação tal qual vinha se consolidando.

Ademais, todas as mulheres que não tinham família nos moldes impostos por essa sociedade, como, por exemplo, as estrangeiras e viúvas, eram consideradas prostitutas e, sem outras oportunidades, muitas de fato encontravam meios de sobrevivência apenas na atividade de prostituição. (ROBERTS, 1998, p. 32).

O governador de Atenas, Solón, perspicaz, percebeu nessas profissionais a possibilidade de aumentar os recursos, de auferir grandes lucros, oportunidade em que criou "bordéis oficiais", espaços destinados à prostituição, vinculados e administrados pelo próprio Estado.

Os homens aplaudiram a ideia de Sólon. O poeta Filemon enviou carta agradecendo por promover “a legitimidade de uma medida de diversão pública” (ROBERTS, 1998, p. 35). Para Moçouçah, "tratou-se de uma correlação de forças que visava retirar poderes políticos das prostitutas, além de mercantilizar a prostituição” (2013, p. 35)

Nesses bordéis oficiais a condição de vida das mulheres era precária. O dinheiro pago pelos serviços era entregue a um homem responsável por administrar e repassar parte do valor às profissionais. Percebe-se, nesse momento, o início da exploração dessa mão de obra, surgindo a figura do cafetão. (ROBERTS, 1998, p. 37)

Nesse mesmo período, segundo Nickie Roberts (1998, p. 45), já era possível encontrar homens "prostitutos", que eram identificados dessa forma por andarem com roupas coloridas e até maquiados.

A prostituição crescia e as mulheres eram rejeitadas pela sociedade, mas, ao mesmo tempo, admiradas por muitos, por serem independentes, por terem dinheiro para comprar o que bem desejassem e pelo fato de conseguirem estudar filosofia, artes, entenderem de política e terem acesso às instruções que não eram passadas às "mulheres de bem", às moças de família.

Em outra grande civilização, a Romana, a prostituição consolidou-se facilmente, até porque essa sociedade era conhecida como ambiente de "perdição" moral e sexual. A aristocracia romana permitia privilégios a poucos. A elite social podia usufruir toda regalia, tais como festas, bebidas, bem com usar os corpos de mulheres e homens para garantir seu prazer, além de bordéis estabelecidos dentro dos próprios palácios. Em contraponto a essa realidade, o Imperador emitia ordens para a maioria do povo contra a libertinagem. 
Com casamentos arranjados, as jovens se casavam cedo, a partir dos 13 anos e os homens, se não econtrassem amor e prazer sexual no lar, buscavam as prostitutas fora do casamento. Em Roma não existiam os bordéis administrados pelo Estado, mas tal qual ocorrera na Grécia Antiga, as profissionais também eram obrigadas a se registrar. (NUCCI, 2014, p. 53).

Nesse momento, as profissionais do sexo continuavam espalhadas por toda parte, nas ruas, nos teatros, nos bordéis e tinham assegurado apenas o direito de receber o valor correto pelo trabalho realizado.

Existia ainda outra categoria, as "seguidoras dos acampamentos", que eram mulheres, geralmente escravas, enviadas para os locais em que havia soldados em batalhas. Essas mulheres, além de satisfazer os desejos sexuais dos combatentes, cuidavam dos afazeres domésticos e das feridas dos soldados. Nickie Roberts destaca:

\footnotetext{
Esta exploração das escravas do sexo pelos soldados resume a organização da indústria do sexo da classe inferior na antiga Roma. Em uma sociedade em que a escravidão era a norma, onde uma imensa massa de escravos existia com o único propósito de criar riqueza para o benefício de uma minúscula elite, era inevitável que o trabalho sexual se desenvolvesse paralelamente, com massas de mulheres (e crianças) dedicando suas vidas de trabalho ao prazer daqueles que tinham dinheiro. (1998, p. 77)
}

Com o início do império de Constantino, o primeiro imperador cristão, todas as atividades econômicas, inclusive a prostituição, passaram a ser tributadas. O Estado lucrava de forma direta com a atividade das profissionais do sexo.

O enfraquecimento do Império Romano, a partir das invasões de tribos por volta do século V d.C. resultou no esvaziamento das cidades; a vida no ambiente rural intensificou-se, dificultando a atividade das profissionais do sexo.

\subsection{Maria Madalena - o estereótipo da prostituta arrependida}

A imagem da profissional do sexo como mulher má, exemplo de pecado e tristeza, dissociada da Deusa sagrada, foi difundida por alguns intérpretes da Bíblia Sagrada. Maria Madalena recebeu o rótulo de prostituta que, ao encontrar Jesus Cristo, arrepende-se e o segue, sem cometer novamente o pecado.

Assim, em razão do rótulo imposto, a figura de Maria Madalena passou a ser vista como o contraponto da mulher ideal. Maria, mãe de Jesus, representaria imagem do exemplo a ser seguido, de mulher dedicada à família, virgem e dócil. 
Aliás, outra dualidade interessante presente nos registros biblícos é a ideia do corpo como lugar de pecado, tentação e morte, em contrapartida a alma como lugar de virtude, salvação e eternidade. Assim, aqueles que buscassem atender seus anseios sexuais estariam se distanciando do céu, rumo ao inferno. Por essa razão, a figura da mulher foi vinculada ao pecado.

A Igreja preconizava ainda a máxima: as prostitutas que não se arrependessem seriam mulheres más e sofredoras. Esses rótulos foram tão introjetados no pensamento da sociedade que até hoje existe o estigma da profissional do sexo como mulher má e pecadora, sendo que muitas dessas mulheres dizem que desejam "sair dessa vida", ter uma profissão de verdade, tornar-se mulher "direita", honesta, porque o dinheiro recebido é sujo e causa vergonha e sofrimento.

A Bíblia Sagrada (2002), em momento algum, relata que Maria Madalena tenha sido prostituta. A passagem em que ela é, pela primeira vez, expressamente identificada encontrase em Lucas, capítulo 8, versículo 2, que diz:

\begin{abstract}
...andava Jesus de cidade em cidade, e de aldeia em aldeia, pregando e anunciando o evangelho do reino de Deus; e iam com ele os doze, bem como algumas mulheres que haviam sido curadas de espíritos malignos e de enfermidades: Maria, chamada Madalena, da qual tinham saído sete demônios. (grifos nossos)
\end{abstract}

É temerário dizer que os sete demônios descritos na passagem qualifiquem Maria Madalena como prostituta; os demônios poderiam representar diversas situações, inclusive enfermidades, físicas ou ligadas à alma.

A famosa passagem bíblica em que Jesus perdoa a mulher adúltera está descrita em João (2002), capítulo 8, versículo 53. Nela, os escribas e fariseus apresentaram a Jesus uma mulher apanhada em flagrante adultério, questionando-o sobre o cumprimento da Lei de Moisés, que determinava o apedrejamento da mulher. No entanto, Jesus desafiou-os, dizendo que aqueles que não tivessem pecados, atirassem a primeira pedra.

Segundo Paul Gardner (2005, p. 284) na obra Quem é quem na Bíblia Sagrada, “ $a$ tradição eclesiástica há muito tempo identificou Maria Madalena como a 'mulher da cidade '”, ou seja, a prostituta perdoada por Jesus.

Entretanto, em momento algum há menção do nome dela na referida passagem e a mulher adúltera pode ser ainda entendida como aquela que traiu o marido e não necessariamente mulheres que eram prostitutas. 
Interessante observar ainda a expressão "mulher da cidade" citada por Gardner, que parece refletir a ideia de que o espaço da mulher era o privado, enquanto o do homem era o público. Diante disso, a prostituta poderia ser entendida como aquela que estaria no "lugar errado", ocupando parte daquilo que pertence ao homem.

Segundo Cadaval (2002), o cristianismo pode ser considerado um marco histórico da prostituição, eis que as questões sexuais passaram do domínio civil para o domínio religioso.

Talvez a figura de Maria Madalena tenha sido incluída nessa situação por uma necessidade humana de trabalhar na Bíblia algumas questões que atormentavam a sociedade daquela época, inclusive pela necessidade de incluir posturas morais que atendessem aos anseios políticos e econômicos daquele povo.

Nesse mesmo sentido, o filósofo francês Jean-Yves Leloup, estudioso de Maria Madalena, em entrevista ao Jornal Estado de São Paulo, esclarece que ela era uma mulher à frente de seu tempo: "Maria Madalena era considerada como fora-da-lei por várias razões. Inicialmente, mesmo sendo mulher, ela se interessava pelos estudos, pelo conhecimento da Torá, o que fez com que se distanciasse do que era tido como conveniente para uma mulher". (BRASIL, 2004)

Há registros, inclusive, de um Evangelho apócrifo que teria sido escrito por Maria Madalena, mas que não foi inserido na Bíblia Sagrada. É possível pensar que a Igreja tenha rejeitado os registros de Maria, da cidade de Magdala, para manter a ideia de submissão e incapacidade da mulher.

Outra importante passagem bíblica está no Evangelho de Lucas (2002), capítulo 7, versículos 36, em que Jesus foi à casa de um fariseu e uma mulher pecadora aproximou-se dele e começou a chorar a seus pés. A passagem relata que suas lágrimas regavam os pés de Jesus e ela os enxugava com seus cabelos.

Por muitos anos, filmes e outras obras trouxeram a figura de Maria Madalena como sendo essa mulher pecadora. Entretanto, mais uma vez, o texto não identifica a referida Madalena e não está explícito que a pecadora aí mencionada fosse prostituta.

Somente em 1969, o Vaticano reconheceu que a pecadora que ungira os pés de Jesus não era Maria Madalena. Entretanto, tal informação ainda é desconhecida por muitos e a imagem de prostituta arrependida nela permanece. (Veronese, 2008)

Maria Madalena, independentemente de quais pecados realmente possuía e quais a ela tenham sido injustamente atribuídos, continua representando uma mulher determinada, forte e 
independente, que esteve presente nos momentos mais importantes da vida de Jesus, tendo sido, inclusive, a primeira pessoa a vê-lo após a sua ressurreição, segundo a Bíblia Sagrada.

O Evangelho, nas passagens citadas, não fala expressamente sobre prostituição. Isso é certo. A interpretação posterior acabou por associar a figura de Maria Madalena a mulher adúltera e daí, por uma distorção, a da prostituta arrependida.

\section{AS PROSTITUTAS NO PERÍODO FEUDAL}

O feudalismo implantou uma forma de vida diferente, em que os servos trabalhavam nas terras dos senhores feudais e tinham uma pequena gleba de terra para sua subsistência e a de suas famílias.

Como a principal fonte de riqueza dos senhores era a terra, buscava-se constantemnte a expansão da propriedade, o que, em muitos casos, gerava guerra entre senhores. Os servos também atuavam nesses conflitos para defender os interesses dos seus senhores, na propriedade ou fora dela. Ocore que quando saiam ou perdiam a guerra, muitos servos saiam em busca de novos trabalhos. As mulheres, dentre elas viúvas, filhas desses, eram comumente exploradas sexualmente (ROBERTS, 1998, p. 90).

A transição desse período de vida exclusivamente no campo começou a acontecer com o surgimento de novas técnicas de cultivo, o que gerou considerável aumento na produção agrícola e a necessidade de comercializar os produtos excedentes.

Nesse contexto, as vilas e cidades começaram novamente a crescer e, com a melhora da produção, os servos conseguiam pagar as suas dívidas com os senhores e passar a viver nos burgos.

As profissionais do sexo, então, voltaram para as cidades e se estabeleceram em bordéis um pouco afastados ou atendendo em suas próprias casas. $\mathrm{O}$ desejo da sociedade e da Igreja em vilipendiar a prostituição era tamanho que "em oposição à prostituta sexualmente afirmativa e financeiramente independente, a Igreja promoveu a freira pia a um ideal de mulher, com seus votos de pobreza, castidade e, acima de tudo, obediência”. (ROBERTS, 1998, p. 97)

Nesse mesmo sentido, iniciou-se também uma campanha para "salvar" as prostitutas pecadoras que se arrependessem; foram criados abrigos, denominados "Lares de Madalena" para amparar as mulheres que clamavam por "nova vida". 
Tomás de Chobham, no Manual para os Confessores do século XIII, dizia que as prostitutas não eram diferentes de outras comerciantes e trabalhadoras, só alugavam seus corpos como forma de trabalho. Entretanto, se a profissional sentisse prazer, ela não poderia aceitar o pagamento porque nesse caso já não estaria configurada a hipótese de trabalho. (SCHLINDWEIN, 2009, p. 45) Percebe-se aqui que a ideia de trabalho deveria estar completamente desvinculado do prazer; não se cogitava a possibilidade de fazer algo que verdadeiramente gerasse bem estar.

Várias leis tentaram regulamentar/proibir de alguma forma a prostituição. A principal delas, o Código do século XII, de Afonso IX de Castela, não tratava a prostituição como ilegal, mas condenava os cafetões e os maridos que escravizavam suas mulheres, bem como trazia restrições à atividade, que na prática inviabilizava sua manutenção.

Embora a Igreja se manifestasse contrariamente à prostituição, o clero era frequentemente criticado pela hipocrisia com que agia:

\footnotetext{
Há mosteiros onde não há disciplina, e que são piores que bordéis (...) um monge pode ficar bêbado todos os dias. Pode se encontrar com mulheres perdidas tanto em segredo quanto abertamente. Pode gastar o dinheiro da Igreja em prazeres pecaminosos. Pode ser um curandeiro e um charlatão e, de vez em quando, um excelente irmão, pronto para ser promovido a abade. (ROBERTS, 1998, p. 109)
}

Prostitutas eram contratadas para oferecer seus serviços nos Concílios da Igreja e atuavam até mesmo dentro do próprio Vaticano. A nobreza e os membros do clero também lucravam com essas atividades, eis que eram proprietários de grande parte dos bordéis das cidades.

Da mesma forma, a Igreja como instituição também se beneficiava dos valores auferidos pela exploração da prostituição. Segundo Roberts, “em 1161, em um singular 'decreto para a administração das saunas', o Rei Henry II garantiu o direito dos bispados de explorar os bordéis de Southwark durante os próximos 400 anos e muitas igrejas de Londres foram, subsequentemente, construídas às custas da prostituição”. (1998, p. 115) Os bordéis administrados pelo Estado também expandiram-se em toda Europa.

Já na crise do feudalismo, em meados dos séculos XIV e XV, as guerras e a Peste Negra mataram parte da população, gerando grave crise econômica. A produção de bens e produtos despencou e a mão de obra, já escassa, tornou-se dispendiosa para os nobres. As profissionais do sexo também sofreram com a crise: vários bordéis foram fechados.

Os bordéis oficiais garantiram a restituição de alguns direitos às profissionais do sexo. Relatos históricos demonstram que essas mulheres reivindicaram direitos por meio de greves. (ROBERTS, 1998, p. 125) Em algumas cidades uma dessas reivindicações era que os bordéis 
fossem administrados pelas próprias mulheres, tendo elas logrado êxito, a título de exemplo, em Avignon, na França.

No século XIV iniciou-se o Renascimento na Europa, período marcado por um pensamento mais racional, em que a Igreja já não conseguia ditar as regras a serem seguidas pela sociedade. Havia ainda uma busca pelos antigos pensadores da cultura clássica e avanços na economia e até mesmo na política.

O retorno à filosofia clássica, entretanto, fez intensificar o pensamento de que a mulher era subordinada e inferior ao homem, razão pela qual a eles cabia administrar o Estado e ser responsável financeiramente pelo lar. Com isso, a vida das mulheres que vinham alcançando pequena liberdade, reduziu-se novamente à casa, sendo que raramente elas conseguiam autorização dos maridos para sair. A ideia da mulher direita, correta e honesta passou novamente a estar intimamente ligada à virgindade, à pureza.

Estima-se que nesse período Veneza tivesse aproximadamente 20 mil profissionais do sexo e a demanda era tamanha que foi preciso trazer mulheres estrangeiras para atender os inúmeros clientes. (ROBERTS, 1998, p. 132-134) Isso demonstra que independentemente do estigma, a profissão ainda guardava atrativos.

Avançando no tempo, já no século XVI, o Protestantismo, um movimento de reação contra os dogmas e doutrina da Igreja Católica, modificou um pouco a realidade. O Manifesto de Lutero apoiava o casamento e o sexo para fins de procriação, mas condenava a promiscuidade dos jovens e a prostituição.

Seguindo essa orientação, os bordéis públicos foram fechados, principalmente na Alemanha, oportunidade em que as profissionais do sexo reagiram:

\footnotetext{
Quando expulsas dos bordéis de Estrasburgo, as mulheres fizeram uma petição em que declaravam que exerciam sua profissão, não porque gostassem dela, mas porque precisavam ganhar a vida. Por isso, se as autoridades estavam determinadas a privá-las de seus meios, precisavam pelo menos estar preparadas para proporcionar às mulheres um meio alternativo 'honesto' de sobrevivência. (ROBERTS, 1998,p. 143)
}

As autoridades alemãs fizeram pequeno esforço para encontrar soluções para as indagações das profissionais do sexo, mas, não logrando êxito, elas permaneceram sem trabalho e sem dinheiro.

Em outros locais a proibição continuava. Em Roma, a Igreja Católica lutava para acabar com a atividade e na França prostitutas eram expulsas de suas cidades, obrigadas a pagar multas, eram presas ou sofriam torturas, como, por exemplo, mulheres que tiveram suas 
orelhas cortadas. Tudo isso tinha uma razão de ser: "E como acontece com todos os sistemas de controle social, a sexualidade era um alvo importante da Igreja e do Estado, o controle dos corpos das pessoas sendo a chave para controlar suas mentes e ações" (ROBERTS, 1998, p. 144-145).

Nem a sífilis, identificada em 1495 entre os soldados franceses e considerada castigo de Deus, foi suficiente para abalar o comércio do sexo. A prostituição continuou existindo, os clientes continuavam procurando esses serviços e os exploradores da atividade continuavam lucrando. Com a elite social se beneficiando economicamente, a perseguição direta à prostituição dá uma pausa. Mais uma vez, o discurso lançado vai de encontro aos verdadeiros anseios e interesses da sociedade dominante.

O "mal necessário" continuou existindo, algumas mulheres tornando-se independentes dos homens, ganhando dinheiro e tendo como maiores clientes os poderosos, os representantes dos Estados e os membros da própria Igreja. Outras viviam em extrema miséria, mas ainda assim permaneciam na prostituição pela falta de opção de vida.

\section{A PROSTITUIÇÃO NOS SÉCULOS XVII, XVIII e XIX}

No período da Revolução Inglesa, a partir do século XVII, as profissionais do sexo expandiram seus negócios: começaram a captar clientes nos teatros e posteriormente passaram a atuar também como atrizes. Os bordéis começaram a oferecer novos atrativos: as profissionais ficavam expostas para serem escolhidas pelo cliente; podia-se pagar somente para assistir outro casal, entre outros. Havia ainda casas que tinham apenas mulheres negras, outros estabelecimentos ofereciam as virgens, sendo possível encontrar até mesmo casas que atendiam um público específico, somente membros do clero, por exemplo. (ROBERTS, 1998, p. 191)

O século XVIII foi marcado por grandes transformações na Europa, influenciadas, principalmente, pela Revolução Industrial e pela Revolução Francesa, momento em que se difundiu a valorização da razão em detrimento da emoção, rejeitando a intolerância da Igreja e do Estado e valorizando a família.

Mas as mulheres continuaram a ter papel secundário. Rousseau, um dos líderes desse movimento, explica o papel das mulheres: "são feitas para encantar os homens, e sua função 
adequada é gerar e criar seus filhos (...) a maternidade é uma carreira absoluta e um compromisso em si”. (ROUSSEAU, 1999, p. 518).

O casamento também foi uma instituição muito incentivada, até por ser uma forma de o homem ampliar seu patrimônio, caso conseguisse se casar com mulher de família rica. Ademais, a união pelo casamento estava em plena consonância com a ideia de valorização da família, tão difundida naquela sociedade. A profissional do sexo Roxana, em 1724, critica essa situação, assemelhando o casamento a uma prisão:

a própria natureza do Contrato de Casamento, em suma, não era nada além da renúncia à Liberdade, à Propriedade, à Autoridade e a tudo em favor do Homem; e a Mulher era, na verdade, uma mera Mulher que vinha depois de tudo, ou seja, uma Escrava. (apud ROBERTS, 1998, p. 202)

Embora tenha sido uma época de desenvolvimento industrial e econômico, a realidade de muitos era o desemprego e a pobreza. As mulheres que não conseguiam bons casamentos, muitas vezes, encontravam-se nessa situação. Por isso, tornar-se profissional do sexo era uma forma de subsistência que poderia gerar um ganho financeiro maior do que trabalhar por 14 a 16 horas em atividades como a de costureira, em grandes fábricas. Os salários pagos nas fábricas às mulheres eram muito inferiores àqueles pagos aos homens. Assim, as esposas continuavam financeiramente dependentes dos maridos.

Importante lembrar o fato de que milhares de crianças pertencentes às classes econômicas inferiores eram exploradas sexualmente nos bordéis e viviam em condições extremamente precárias.

A demanda era tão alta que outros comércios da cidade, como cafés e confeitarias, passaram a oferecer espaço, quartos para prostituição. O escritor Restif de La Bretonne, no século XVIII, estimou que em Paris havia 20.000 prostitutas para uma população de 600.000 habitantes. (apud ROBERTS, 1998, p. 214) A relevante quantidade de profissionais demonstra que, embora a sociedade fosse formalmente contrária à atividade, demandava tais serviços.

Entretanto, a perseguição nunca deu trégua. A título de exemplo, neste período, na Áustria, como punição, várias profissionais foram marcadas a ferro, açoitadas, muitas tiveram suas cabeças raspadas, foram presas, obrigadas a varrer a rua em sinal de "reparação pública da vergonha".

Na França, a prostituta era definida como um "problema" para a sociedade, que deveria ser tratado com medidas rigorosas. Várias profissionais do sexo foram internadas em instituições de reabilitação, para se tornarem pessoas melhores. Nesses locais muitas eram 
obrigadas a trabalhar em serviços braçais e pesados, de grande esforço físico. Relatos informam que nessas internações, as mulheres eram vigiadas por homens, principalmente pelo tenente da polícia, que as explorava sexualmente. (ROBERTS, 1998, p. 216)

Interessante pensar que já se valorizava o chamado "trabalho produtivo", aquele gerador de mais valia, excluindo aqueles que não participam desse conceito, tais como mendigos, loucos, vagabundos e as prostitutas. A prisão servia, assim, como forma de reabilitação e ainda para o retorno do sujeito à sociedade seguindo o padrão de trabalho convencional.

Como em momentos históricos anteriores, a prostituição clandestina continuou, principalmente por intermédio dos cafetões, que em geral eram homens que conseguiam manter as casas em funcionamento, sem conhecimento da polícia e das autoridades, ou mediante pagamento de propinas.

Tempos depois, percebendo a dificuldade de acabar com a prostituição, especialmente na França, optou-se por firmar um acordo, estabelecendo regras a serem seguidas para garantir a permanência da atividade. Assim, a título de exemplo, foi estabelecido que as profissionais do sexo só poderiam ocupar áreas e ruas previamente determinadas; aquelas que descumprissem as normas eram severamente perseguidas. Nesse período já existiam os denominados bordéis homossexuais, sendo que aquelas exigências também deveriam ser cumpridas pelos homens. (ROBERTS, 1998, p. 221)

A Revolução Francesa derrubou todas aquelas normas que determinavam locais e forma de exposição das profissionais, razão pela qual elas voltaram aos espaços públicos. Entretanto, pelo Código de Napoleão, de 1804, as mulheres continuaram sendo consideradas incapazes e tidas como propriedade do marido. $\mathrm{O}$ adultério era crime cometido apenas pelas mulheres, pois os homens não sofriam represálias da sociedade pela traição.

Em meio a um contexto de desvalorização da mulher, a vida das profissionais do sexo não foi facilitada, continuaram sofrendo violência de todas as formas. Nos antigos "Lares de Madalena" eram ministradas palestras patrióticas, até porque as mulheres eram vistas como potenciais traidoras da causa revolucionária. (ROBERTS, 1998, p. 230)

Percebe-se que a História registra momentos de grande repressão, inclusive com a diminuição do número de profissionais, mas nunca o fim do comércio do sexo, que consegue reinventar-se, talvez porque a elite da sociedade, que é responsável pela negação às prostitutas é, ao mesmo tempo, aquela que mais lucra e se utiliza dos serviços ofertados. 
Os bordéis começaram a profissionalizar esse negócio tão lucrativo, criando, inclusive, catálogos que anunciavam o trabalho das profissionais ou descreviam sua beleza física:

JAN FOWLER. Alta, magra, de formas e maneiras graciosas; cabelos claros, com uma pele surpreendentemente bonita e transparente; olhos azuis e profundos, adornados por bonitos cílios sedosos, através dos quais seu olhar lança milhares de raios mortais (ROBERTS, 1998, p. 236)

O material era espalhado pela cafetina em clubes e escritórios dos homens ricos. Os homens valorizavam muito as mulheres ainda virgens, pagando elevadas quantias por esses programas. Por isso, os cafetões saíam às ruas para atrair essas meninas, na maioria das vezes ainda na tenra idade. Elas eram levadas aos bordéis e obrigadas a alugar ou comprar roupas mais extravagantes e, com isso, já se endividavam com os cafetões. O ciclo era, portanto, vicioso: as jovens já endividadas não conseguiam deixar de ser exploradas pelos cafetões.

Registre-se ainda que nesse período da Revolução Industrial as crianças já trabalhavam intensamente, inclusive dentro das indústrias, em condições extremamente precárias, durante excessivas jornadas, o que, não raras vezes, acarretava a morte prematura de muitas.

Outra atividade sigilosa e muito velada pela sociedade naquele período, mas bastante lucrativa, eram os bordéis homossexuais, frequentados especialmente por nobres, inclusive membros da família real. Algumas mulheres, também providas de dinheiro, podiam frequentar e escolher o homem que desejassem, mantendo seu rosto coberto por máscaras, para não serem identificadas. (ROBERTS, 1998, p. 240)

Em relação à Revolução Francesa, Roberts explica que "na França, os ideais revolucionários de liberté, egalité e fraternité rapidamente foram interpretados como a liberdade para a burguesia explorar os pobres, a igualdade para aqueles que já eram consideravelmente mais iguais que o resto e uma fraternidade que, por definição, excluía a metade feminina da população” (ROBERTS, 1998, p. 241) e, consequentemente, excluía as profissionais do sexo.

Em 1810, em Paris, a polícia organizou um esquema de atuação para garantir a moralidade. As prostitutas eram obrigadas a se inscrever em um cadastro e passar mensalmente por uma “inspeção vaginal”, realizada pelo médico da polícia, a fim de verificar se haviam contraído doença venérea; se detectada alguma, as mulheres eram levadas, à força, para um hospital-prisão. 
Nesse período, outras normas também foram introduzidas, limitando, por exemplo, os lugares que as profissionais do sexo poderiam frequentar. A violação dessas normas acarretava prisão.

As mulheres trabalhadoras que moravam sozinhas, por exemplo, sofriam represálias. Roberts relata o caso de Amélie Renault, que foi presa por ter saído de casa à noite para comprar remédio para o filho doente. A polícia não acreditou nas palavras da mulher e somente a liberou na manhã seguinte; tendo a acompanhado até sua casa, aí encontraram a criança, morta. (1998, p. 245-246) A crueldade não tinha limites.

Como nos demais exemplos já relatados, as regras implementadas conseguiram “controlar" parcialmente o comércio do sexo; muitas mulheres, porém, continuaram a trabalhar nas ruas, em casas irregulares, frequentemente tendo que fugir da polícia.

$\mathrm{Na}$ Alemanha além de terem sido implementadas as normas de origem francesas, os preços pelos serviços também passaram a ser regulados pelo Estado, sendo que as mulheres recebiam apenas cerca de $1 / 4$ de seus ganhos. A exploração da atividade das profissionais do sexo foi, mais uma vez, legitimada pelo Estado, para garantir seus interesses econômicos e políticos.

Os relatos de prostituição, porém, não se restringiam ao Velho Continente: inúmeras cidades dos Estados Unidos abrigavam bordéis e muitas profissionais do sexo já eram vistas pelas ruas, praças, hotéis:

\footnotetext{
A extensão da licenciosidade e da prostituição é realmente apavorante, e sem dúvidas sem paralelos em todo o mundo civilizado (...) pelo menos três quintos das moradias e dos quartos de grande parte da cidade são ocupados por prostitutas ou por uma ou outra classe de amantes sustentadas. (ROBERTS, 1998, p. 221)
}

Em Orlando, duas irmãs investiram a herança do pai em um bordel de luxo, sendo que após 12 anos já eram consideradas milionárias. As profissionais do sexo que trabalhavam nesse bordel também recebiam elevadas quantias. Enquanto uma mulher teria salário de 1 dólar por semana em outras atividades, ali as prostitutas chegavam a receber 50 dólares por semana. (ROBERTS, 1998, p. 256) Essa informação demonstra que estabelecimentos dedicados à prostituição, em muitos casos, era de fato um bom investimento, um negócio lucrativo e com pouca fiscalização das autoridades.

No século XIX a mulher ainda permaneceu em seu papel secundário e não havia interesse político e econômico de inseri-las na sociedade.

Com o objetivo de repreender os anseios sexuais das mulheres, nesse período, continuou a ser divulgada a ideia de que a mulher não tinha desejos sexuais, os quais estariam 
restritos ao corpo masculino; a mulher deveria ser pura. Ao contrário do esperado, a atividade das profissionais do sexo tornou-se ainda mais procurada, vez que a maioria das mulheres de fato reprimia ainda mais seus desejos e os homens buscavam nas profissionais a possibilidade de se satisfazer sexualmente.

O francês Parent-Duchâtelet, em rude metáfora, diz que "as prostitutas são tão inevitáveis em uma grande cidade quanto os esgotos, as fossas e os depósitos de lixo. A conduta das autoridades deve ser a mesma com relação a cada um deles" (apud ROBERTS, 1998, p. 265)

A História, mais uma vez, se repetia. Embora a prostituta fosse buscada e demandada pela sociedade, continuou sendo criticada: era pessoa "incapaz de fazer escolhas inteligentes, pois a prostituta não possuía inteligência - era apenas carne, impulsos selvagens, paixões e instintos animais”. (ROBERTS, 1998, p. 269) Era considerada ser subumano.

Observa-se que as razões para se prostituir eram inúmeras: muitas mulheres vinham de classe baixa e precisavam do dinheiro para ajudar a família; muitas trabalhavam em fábricas por longas jornadas e complementavam a renda com a prostituição, em razão dos baixos salários recebidos; outras, quando crianças, haviam sofrido abuso sexual por homens da família; outras haviam perdido o pai e tiveram que ajudar financeiramente em casa; outras se revoltaram com a família, em razão da rígida disciplina exigida.

Percebe-se, mais uma vez, que a História se repete: as razões apresentadas pelas mulheres que hoje atuam como profissionais do sexo não diferem das razões ora elencadas. As motivações, embora não seja objeto de análise nesse trabalho, parecem ser ainda as mesmas.

Em relação à figura do cafetão do século XIX, Roberts descreve detalhes surpreendentes:

$$
\begin{aligned}
& \text { eles em geral pertenciam à mesma origem social de suas prostitutas, e por isso } \\
& \text { enfrentavam problemas similares de pobreza e falta de perspectiva (..) a } \\
& \text { cafetinagem era uma das poucas maneiras em que um homem de uma origem } \\
& \text { pobre conseguia uma mobilidade ascendente, ou pelo menos um padrão de vida mais } \\
& \text { elevado (...) um cafetão violento era em geral a menor preocupação de prostituta; por } \\
& \text { outro lado, toda prostituta temia a possibilidade de ser atacada - e até assassinada - } \\
& \text { por um cliente. (1998, p. } 284-285)
\end{aligned}
$$

As profissionais do sexo eram tidas como trabalhadoras rebeldes, independentes e agressivas, talvez pelo medo e necessidade de se impor em meio a tanta violência e repressão e, por isso, eram vistas como uma possível ameaça à sociedade.

Esse medo intensificou-se no final do século XIX. A título de exemplo, o denominado Ato da Polícia Metropolitana, na década de 1850, estipulou a pena para a vadiagem, 
considerando-a uma ofensa. Assim, todo hotel que tivesse moradoras profissionais do sexo era identificado como bordel e o proprietário poderia ser processado. (ROBERTS, 1998, p. 291)

Também foi publicado o Ato das Doenças Contagiosas, principalmente em razão da sífilis que estava matando e contaminando parte da população. A culpa pela doença foi atribuída às profissionais do sexo, que sofreram perseguição; elas eram obrigadas a se internar para tratamento e não raras vezes eram expulsas dos quartos em que moravam, além de serem separadas de seus filhos, que eram levados a reformatórios. "O Ato das Doenças Contagiosas institucionalizou a ausência de direitos humanos e civis básicos das prostitutas e das outras mulheres da classe trabalhadora”. (ROBERTS, 1998, p. 295)

Outra norma foi o Criminal Law Amendment Act, que entrou em vigor em 1885, na Grã-Bretanha e conferia poderes para a polícia agir contra a cafetinagem. A ação da polícia passou a ser tão veemente que em Manchester, por exemplo, o número de bordéis reduziu-se de quatrocentos para apenas 10 e muitas prostitutas foram presas. (ROBERTS, 1998, p. 304)

Com o fim de vários bordéis, muitas profissionais do sexo alugaram quartos para morar e neles continuaram trabalhando. Outras, em menor quantidade, preferiram continuar trabalhando nas ruas, mas deveriam manter vigilância dobrada, pois constantemente tinham que fugir da polícia.

Embora esse movimento tenha ganhado força imediatamente quando lançado, após pequeno intervalo de tempo os ânimos acalmaram-se e os bordéis voltaram a existir nas áreas mais pobres e distantes da cidade.

Em Nova Orleans, a situação no mesmo período era um pouco diferente, especialmente no bairro Storyville, composto de 38 quarteirões exclusivamente de casas de prostituição. Nesse local, a diversidade era um dos diferenciais: era possível encontrar estabelecimentos elegantes e caros, mas também simples e baratos. As casas geravam trabalho para as profissionais do sexo, mas também para garçons, pianistas e outros músicos que se apresentavam no local.

Segundo Roberts, Storyville faturava muito mais de dez milhões de dólares por ano. (1998, p. 309) Há registros ainda de que vários políticos eram proprietários de bordéis na região, lucravam imensas quantias e, pela influência na sociedade, protegiam as mulheres da perseguição da polícia. 
Já em Washington, com a decretação do fim dos bordéis, as profissionais do sexo uniram-se e enviaram carta às autoridades relatando o desamparo do Estado e a dificuldade de conseguir novas oportunidades:

Sabendo que a opinião pública está contra nós, e que a aprovação (...) "Lei do Prostíbulo" é certa, nós, profissionais do submundo, queremos saber como o público espera que possamos sobreviver no futuro?

Nós não queremos "lares". Tudo o que perguntamos é que posições nos serão oferecidas. A maioria irá aceitá-las. Precisamos sobreviver de alguma forma. Somos humanas. Com todos os estabelecimentos de quase todas as grandes cidades fechados, é inútil sairmos de Washington.

Quantos cidadãos darão emprego às mulheres da nossa classe? Poucos terão mentes tão liberais (...) No passado, isso foi tentado e assim que as reputações anteriores foram descobertas, nossas situações tornaram- se insuportáveis. Então, por necessidade, tivemos que voltar à antiga vida. (ROBERTS, 1998, p. 314)

As lutas travadas pelas prostitutas. Em várias partes dos Estados Unidos o pensamento e a ação foram no sentido de abolir a prostituição, todavia, não tiveram êxito.

No mesmo período, a Europa experimentava menor violência contra essas profissionais, mas ainda assim elas eram obrigadas a se registrar, declarar suas intenções e local em que exerceriam suas atividades, sob pena de prisão.

\section{AS PROSTITUTAS NO SÉCULO XX}

O século XX foi marcado pela Grandes Guerras, Revolução Russa, o Nazismo e o Facismo, dentre outros grandes movimentos que foram objeto dos holofotes da sociedade, principalmente na Europa.

Como em outros períodos da História, as tradições oscilam de tempos em tempos. A título de exemplo, nesse século a prostituta voltou a ser importante para garantir ao jovem sua primeira experiência sexual; posteriormente, ele se ocuparia em garantir um casamento decente.

Esse período foi marcado também pelo fato de a sociedade ter se tornado ainda mais industrial, principalmente com a ampliação da produção de bens de consumo e a intensificação do comércio. Com maior número de postos de trabalho disponíveis, muitas mulheres garantiram oportunidades, principalmente em lojas, cargos administrativos em escritórios e consultórios, passando a contribuir financeiramente no lar. 
Entretanto, os salários continuaram baixos e muito inferiores àqueles pagos aos homens, desestimulando a permanência de muitas mulheres no mercado e fazendo com que parte delas optasse pela prostituição.

Nos Estados Unidos, diferentemente do que aconteceu na Europa, os períodos da primeira e segunda Guerras Mundiais foram marcados pela exploração sexual e por medidas de repressão. Em 1919 foi proibido o consumo de álcool e vários estabelecimentos americanos passaram a ser controlados por gangues de criminosos, que mantinham a venda ilegal de bebidas e exploravam a atividade das profissionais do sexo, ganhando percentual sobre o valor por elas auferido.

Essa situação começou a ser modificada quando uma corajosa profissional do sexo apresentou-se ao Tribunal e denunciou a exploração. O líder das gangues foi preso e condenado a mais de 30 anos pelo crime de prostituição compulsória. Segundo relatos da referida prostituta, em um ganho mensal de 260 dólares, a profissional poderia reter apenas 13 dólares, sendo o restante destinado às facções criminosas. (ROBERTS, 1998, p. 329)

Fazendo uma análise geral de alguns países, tem-se que na Rússia, por volta de 1920, as profissionais do sexo também sofreram represálias. Muitas foram detidas e enviadas para serem "reeducadas em um espírito proletário”, após o que eram enviadas a fábricas, para que começassem a exercer um verdadeiro trabalho.

Registre-se, mais uma vez, que as represálias aqui narradas aconteciam principalmente com as profissionais mais simples, com menor instrução e renda, até porque os bordéis frequentados pela alta sociedade permaneciam alheios às regulamentações, por estarem protegidos por homens poderosos. A violência sempre esteve presente na história da prostituição.

Outro importante fato histórico que não deve ser olvidado é o regime nazista e facista. Embora Hitler e Mussolini permitissem a existência dos bordéis regulamentados, a sociedade era patriarcal, privilegiava a mãe de família e, portanto, reprimia de fato o comércio do sexo. Alia-se a isso ainda o fato de que muitas prostitutas eram estrangeiras e judias, razão pela qual grande parte delas foi encaminhada aos campos de concentração.

Em 1945, com o fim das guerras, a economia ascendeu, a produção intensificou-se, a sociedade tornou-se mais consumista e novamente foram oferecidas oportunidades de trabalho às mulheres da sociedade, mas, do mesmo modo, trabalhos com baixos salários, o que mantinha grande parte delas na prostituição. 
Na Itália e na França, em 1956, foi aprovado o Ato das Ofensas Sexuais, que proibia as mulheres de se "oferecerem" para os homens, chamando-os à prostituição. Cabia à polícia analisar a situação concreta, sendo que eram proibidas "não só as palavras proferidas mas também vários movimentos da face, do corpo e dos braços, como sorrir, piscar, fazer um gesto e acenar ou mexer o corpo de uma maneira que indique um convite à prostituição". (ROBERTS, 1998, p. 337)

Percebe-se que, pela abrangência da norma, a perseguição acontecia em relação a qualquer mulher e não apenas às profissionais do sexo. Amedrontadas, as mulheres reprimiam seus sentimentos, seus gestos de afeto, para se livrarem da aplicação do Ato das Ofensas Sexuais.

Nos Estados Unidos, os policiais utilizavam diversos métodos para proceder à prisão de uma profissional do sexo:

\footnotetext{
Parecia que estava tudo certo com ele, mas achei que devia conhecê-lo melhor. Ele estava um pouco nervoso. Olhava muito em volta e nunca me olhava nos olhos. Depois, antes sequer de se vestir, pegou suas credenciais e me disse que eu estava presa.

A polícia (...) Washington estabeleceu um serviço falso de acompanhantes (...) ela colocava anúncios no jornal, recrutando empregados e clientes. As propagandas para recrutar prostitutas ofereciam apenas um emprego bem remunerado. Era perguntado às mulheres que respondiam aos anúncios - muitas das quais jamais haviam trabalhado como prostituta antes - se elas estariam dispostas a se envolver na prostituição. Quando concordavam, eram presas. (ROBERTS, 1998, p. 341)
}

A ideia do sexo como contrário aos padrões morais foi flexibilizada na década de 60 , quando o sexo passou a ser visto como algo natural, sem exigência no sentido de que a mulher se casasse virgem, para conseguir um marido. A flexibilização, todavia, não foi suficiente para retirar o estigma negativo da prostituição.

Finalmente, movimentos mais amplos em defesa das profissionais do sexo começaram a surgir. Na década de 70, nos Estados Unidos, especialmente em São Francisco, foram deflagrados movimentos para dar proteção e voz às profissionais do sexo. Nessa época, surgiu o Movimento Nacional da Prostituição.

Assim, esses movimentos começaram a se expandir. Na França também foi criada a Associação das Prostitutas Francesas; o mesmo ocorreu na Inglaterra. A polícia inglesa reagiu, buscando pôr fim à união das profissionais, mas a comunidade, principalmente a feminina, apoiou a iniciativa, solidarizando-se com elas. 
O movimento teve êxito e exigências foram aceitas pelo Estado, tais como: o fim das prisões ilegais, fim das ameaças e chantagens da polícia, fim das prisões dos filhos das profissionais, dentre outras.

Com o sucesso dos movimentos, as Associações foram espalhando-se em vários países, como a Áustria e o Canadá, este que foi o responsável por organizar a primeira Marcha do Orgulho da Prostituta em 1982. O país norte-americano possui um órgão denominado Canadian Organization for the Rights of Prostitutes, que busca estabelecer o diálogo do grupo com a comunidade.

Em 1986, graças à união dessas inúmeras Associações, foi formada a Associação Internacional das Prostitutas. As conquistas conseguidas principalmente com a atuação das organizações de classe, representam avanços.

Segundo Roberts, “marca o início da luta para a reconsideração como seres humanos plenos, mas também significa a reclamação da antiga dignidade e autonomia sexual da prostituta-sacerdotisa roubada no processo de repressão ao longo dos séculos” (1998, p. 412)

\section{CONCLUSÃO}

A prostituição existe desde as primeiras civilizações e já se posicionou na sociedade de forma distinta. Em um primeiro momento, as práticas sexuais eram vinculadas às Deusas, em adoração pela possibilidade de reprodução.

Na Grécia Antiga, a sociedade já havia deixado de ser matricêntrica para ser patriarcal, oportunidade em que os homens ocupavam os cargos públicos e eram responsáveis pela manutenção econômica do lar. A mulher passou a ter papel secundário na sociedade.

Dentro desse cenário, a prostituição tampouco deixou de existir. A História demonstra a hipocrisia da sociedade ao estigmatizar as profissionais do sexo, mas ao mesmo tempo requerer os seus serviços. O estigma veio carregado, inúmeras vezes, de violência e até mesmo tortura, com atos de prisão, penas que degradam o ser humano e até mortes.

A situação das profissionais do sexo melhorou muito em relação aos relatos . Embora ainda exista violência por parte dos clientes e dos próprios intermediadores da mão de obra (cafetões) e até descaso das autoridades, inclusive da polícia, tais atos não são amparados pelo próprio Estado.

A narrativa histórica da prostituição na sociedade demonstra os percalços vividos pelas profissionais do sexo. Vários deles, como dito, permanecem presentes até os dias de 
hoje. Em um Estado Democrático de Direito todas as pessoas merecem ser respeitadas e amparadas, devendo prevalecer sempre o Princípio da Dignidade da Pessoa Humana, constitucionalmente garantido.

\section{REFERENCIAS}

BARROS, Alice Monteiro de. Curso de Direito do Trabalho. $2^{\mathrm{a}}$ ed. São Paulo: LTr, 2006.

BRASIL. Ministério do Trabalho e Emprego. CBO - Classificação Brasileira de Ocupações, 2002. Disponível em: <http://www.mtecbo.gov.br/cbosite/pages/home.jsf> Acesso em 20 de fevereiro de 2015.

BRASIL, Ubiratan. Jean-Yves Leloup garante que ela era fora-da-lei e não uma prostituta. Disponível em: <http://www.salmo133.org/s133/control/publications/public/Sangreal_MM03.php> Acesso em 27 de abril de 2015.

DELGADO, Maurício Godinho. Curso de Direito do Trabalho. 10ª ed. São Paulo: LTr, 2011.

ENGELS, Friedrich. A origem da família, da propriedade privada e do Estado. São Paulo: Alfa Ômega, 1986.

FERNANDES, Daniela. Mais de 40 milhões se prostituem no mundo, diz estudo. 2012. Disponível em

http://www.bbc.co.uk/portuguese/noticias/2012/01/120118_prostituicao_df_is.shtml> Acesso em 15 de abril de 2015.

FOUCAULT. Michel. História da sexualidade. Tradução de Maria Thereza da Costa Albuquerque e J. A. Guilhon Albuquerque. 13a ed. São Paulo: Graal, 1999.

GARDNER, Paul. Quem é quem na Bíblia Sagrada. Tradução de Jaime Clasen. Rio de Janeiro: Sindicato Nacional dos Editores de Livros, 2005.

HOUAISS, Antonio; VILLAR, Mauro de Salles. Dicionário Houaiss da língua portuguesa. 2 ed. Rio de Janeiro: Objetiva, 2004.

JOÃO. In: A BÍBLIA: tradução ecumênica. São Paulo: Paulinas, 2002.

LOPES, Ana. Trabalhadores do sexo, uni-vos! Organização laboral na indústria do sexo. Lisboa, Portugal: Dom Quixote, 2006.

LUCAS. In: A BÍBLIA: tradução ecumênica. São Paulo: Paulinas, 2002. 
MÉIS, Carla de. Prostituição e Marginalidade: narrativas de identidade entre prostitutas. In: RENAULT, Luiz Otávio Linhares; VIANA, Márcio Túlio; CANTELLI, Paula Oliveira, coordenadores. Discriminação. $2^{a}$ ed. São Paulo: LTr, 2010, p 446-466.

MOÇOUÇAH, Renato de Almeida Oliveira. Trabalhadores do sexo e seu exercício profissional: um enfoque pelo prisma da ciência jurídica trabalhista. 2013. 238f. Tese (Doutorado) - Universidade de São Paulo (USP), Programa de Pós Graduação da Faculdade de Direito, São Paulo.

NUCCI, Guilherme de Souza. Prostituição, Lenocínio e Tráfico de Pessoas: aspectos constitucionais e penais. São Paulo: Revista dos Tribunais, 2014.

RAGO, Margareth. Os prazeres da noite: prostituição e códigos da sexualidade feminina em São Paulo, 1890-1930. 2a ed. São Paulo: Paz e Terra, 2008.

ROBERTS, Nickie. As prostitutas na história. Tradução de Magda Lopes. Rio de Janeiro: Rosa dos Tempos, 1998.

ROUSSEAU, J.J. Emílio ou Da Educação. Trad. Roberto Leal Ferreira. Martins Fontes. 2a Ed. São Paulo. Martins Fontes. 1999.

RUSSOMANO. Mozart Victor. Comentários à Consolidação das Leis do Trabalho. $17^{\mathrm{a}}$ ed. Rio de Janeiro: Forense, 1997.

SCHLINDWEIN, Ana Flora. Páginas Davida. Um gesto analítico discursivo sobre a prostituição. 2009. 143f. Dissertação (Mestrado) - Universidade de Campinas, Campinas, SP.

SUSSEKING, Arnaldo; MARANHÃO, Délio; SEGADAS, Viana. Instituições de Direito do Trabalho. $12^{\mathrm{a}}$ ed. São Paulo. LTr, 1991.

VIANA, Márcio Túlio. 70 anos de CLT: uma história de trabalhadores. Brasília: Tribunal Superior do Trabalho, 2013.

VERONESE, Michelle. A história secreta do cristianismo. Disponível em: < http://super.abril.com.br/religiao/historia-secreta-cristianismo-447676.shtml> Acesso em 27 de abril de 2015. 